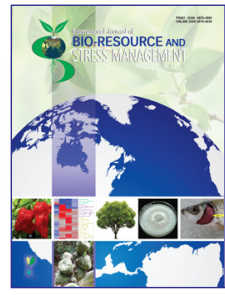

\title{
Biodiversity of Old-growth Coniferous Forests in the Ural Mountains
}

\author{
Natalya Sergeevna Ivanova
}

Botanical Garden of the Ural Branch of the Russian Academy of Sciences, Yekaterinburg, Russia, Ural State Forest Engineering University, Yekaterinburg, Russia

\section{Open Access}

\section{Corresponding Author}

Natalya Sergeevna Ivanova

e-mail: i.n.s@bk.ru

Citation: Ivanova, 2019. Biodiversity of Oldgrowth Coniferous Forests in the Ural Mountains. International Journal of Bio-resource and Stress Management 2019, 10(3):251-256. HTTPS://DOI. ORG/10.23910/IJBSM/2019.10.3.1985

Copyright: (c) 2019 Ivanova. This is an open access article that permits unrestricted use, distribution and reproduction in any medium after the author(s) and source are credited.

Data Availability Statement: Legal restrictions are imposed on the public sharing of raw data. However, authors have full right to transfer or share the data in raw form upon request subject to either meeting the conditions of the original consents and the original research study. Further, access of data needs to meet whether the user complies with the ethical and legal obligations as data controllers to allow for secondary use of the data outside of the original study.

Conflict of interests: The authors have declared no conflict of interests exist.

Acknowledgement: The paper is written under the State order of the Botanical garden of the Ural Department of the Russian Academy of Sciences.

\begin{abstract}
Due to a steadily growing human-induced impact on the biosphere, natural biological diversity preservation and support for forest ecosystems and their dynamics forecast is one of the most urgent global issues. The aim of our research was to identify geographical and landscape diversity features of the mountain forests of the South and the Middle Urals (Russia) based on forest typology, landscape ecology and vegetation science approaches. As a result of the long-term research (1991-2017), quantitative data on biological diversity of old-growth coniferous forests were obtained. Productivity and species saturation of the subordinated layer was studied. It was established that a diversity of forest vegetation conditions and an ecotone effect lead to modern forest type diversity. The research has complemented data on forest types with information on productivity and species saturation for a herb and shrub layer of nominally primary forests. A natural biodiversity level required to preserve natural ecosystem stability was identified. The minimum values are revealed at steep slopes and upper mountains, both in the Southern, and the Middle Urals. The largest species saturation is revealed in lower smooth slopes for moss spruce forests of the Southern Urals and for Multi-herb pine forest of the Middle Urals. The carried-out analysis has shown the advantages for joint use of forest typology, landscape ecology and floristic analysis methods for forest vegetation research. The conducted work forms a scientific basis for biodiversity preservation of the Ural mountain forests, their regional and landscape dynamics research, justified forecast of forest resource conditions.
\end{abstract}

Keywords: Old-growth coniferous forest, biodiversity, Ural Mountains

\section{Introduction}

Due to a steadily growing human-induced impact on the biosphere, natural biological diversity preservation and support for forest ecosystems and their dynamics forecast is one of the most urgent global issues (Maiti et al., 2016; Zobel, 2016). A number of works are devoted to the given issue. Climatic changes, cuttings and fires are recognized as the most significant factors transforming the structure and functions of forest ecosystems (Mirkin et al., 2010; Chen et al., 2011, Murray et al., 2017; Schaphoff et al., 2016). Despite numerous publications on a biodiversity issue, there is still insufficient reliable understanding of scope of changes ongoing in forest ecosystems, biodiversity interdependency and sustainability of natural systems (Lankin, Ivanov, 2011; Westgate et al., 2013).

There are more than $20 \%$ of the world forest ecosystems in Russia.

\section{Article History}

RECEIVED in $16^{\text {th }}$ April 2019 RECEIVED in revised form $30^{\text {th }}$ April 2019 ACCEPTED in final form 30 $30^{\text {th }}$ May 2019 
It is of a primary significance for biosphere perseverance (Global Biodiversity Outlook 2, 2006) and are the major national treasure for Russia. The Ural forests are located at the boundary between Europe and Asia: at the joint of two florae. This forests have exceptional climate-regulating and water-protective value. Ecotone location promotes greater vulnerability of the Ural forests to climatic changes and anthropogenic influences in comparison with the forests located in other regions.

The aim of our research was to identify geographical and landscape diversity features of the mountain forests of the South and the Middle Urals (Russia) based on forest typology, landscape ecology and vegetation science approaches.

\section{Materials and Methods}

The research was conducted in the western low-hill terrain of the Southern Urals and the Zauralsky hilly piedmont province of the Middle Urals. Based on the climatic geography of the territory of the Russian Federation (Alisov, 1956), the mountainous Southern and Middle Urals are included in the Continental Atlantic forest area of the temperate zone.

Damp and cool Atlantic air masses have an impact on the western low-hill terrain of the Southern Urals during the most part of the year (Kuvshinova, 1968). The main climate peculiarity is its continentality. Mountain relief roughness and climatic regime dependence on multi-origin air masses (Atlantic and Arctic) bring considerable implications in the generalized characteristic of climatic conditions. A difficult nature of transformation of the Atlantic air masses by the Southern Ural Mountain chains of different heights has an impact on climate change regularities depending on the terrain elevation (Kuvshinova, 1968). This leads to a stronglypronounced altitudinal zonation. A high-altitudinal belt (700-900 $\mathrm{m}$ above sea-level) is distinct in its more contrast temperature condition. Steep slopes with fine bouldery ground, humidity of which is not stable and completely depends on atmospheric precipitation, are most common. Here, fir woods grow, dominated by Polygonum alpinum in the second layers. A middle altitudinal belt (500-700 m above sea-level) is the warmest one due to temperature inversions. Slopes are rolling and steep. Soils are of average thickness. Here nemorose dark-coniferous forests grow. A lower altitudinal belt (400-500 $\mathrm{m}$ above sea-level) is distinct in its long smooth slopes with thick soils which provide stable moistening conditions. Here high-productive dark-coniferous forests grow.

The climate of the Zauralsky hilly piedmont province is formed under the influence of three types of air masses: Atlantic damp and cool air masses, coming from the West; cold and moderately damp polar (Arctic) air masses extending along the Ural range of mountains from the Arctic Ocean; warm and dry continental air masses getting from the plains of Kazakhstan (Kolesnikov et al., 1973). The barrier role of the Ural range of mountains detaining Atlantic damp air masses which are moving to the east (Kolesnikov et al., 1973) has a dominant influence on the climatic conditions. Owing to its meridional orientation, the Ural Mountains promote intensification of climate continentality in the Zauralsky hilly piedmont province (Kuvshinova, 1968). The main climate peculiarities are caused by two factors: low altitudes of submountains and their location on the down-wind macroslope of the Ural dividing mountain range. The first factor defines more favorable indicators of temperature conditions (especially in summer months), and the second factor defines considerable rainfall reduction in comparison with the western Ural macroslope, and therefore reduced moistening. Therefore, dark-coniferous forests common in the western macroslope are interchanged with pine forest types in the east macroslope. Besides, a small range of altitudes does not lead to altitudinal zonation formation. It is cause to note that due to temperature inversions the middle parts of slopes are warmer. Yearly precipitation in the western Southern Ural low-hill terrain makes 580-680 $\mathrm{mm}$ a year, in the Zauralsky hilly piedmont province of the Middle Urals makes 400-500 mm a year.

During more than 250 years, the Ural forests have been subject to intensive forest use, besides over the last decades the intensity of man-induced fires has increased. Vegetation changes are as follows (Filroze, 1978): consecutive reduction of land with primary zonal vegetation types; relative increase in land with secondary leaf bearing forests; decrease in productivity of forest soils due to hydrologic behavior deterioration and erosion phenomena development.

A topographic and ecological profile method including constant and temporary sample plots at index plots is the basis for field studies. Site investigation studies included investigation of lower, middle and top parts of the southern, northern, western and eastern mountain slopes. This stage of work allowed finding the old-growth (least disturbed) forests growing in various forest sites. Sample plots were mapped across these sites. The size of sample plots was selected so that there should be not less than 200 trees from main generation of the prevailing forest-forming species. A relief position (a slope part, its exposition and steepness) was specified for each plot. Soil thickness was defined. To classify the objects, forest type outlines drawn based on forest typology principles (Kolesnikov, 1956; Kolesnikov et al., 1973; Ivanova, Zolotova, 2014) and ecofloristic classification were used (Martynenko et al., 2007; Braun-Blanquet, 1964). Ecofloristic classification allows describing study objects up to the latest world standards (Martynenko et al., 2003; Mirkin et al., 2010)

Forest stand (Anuchin, 1982; Ivanova, 2017), natural wood plant revegetation, a herb and shrub layer (Yarmishko, Lyanguzova, 2002) were studied on sample plots by means of time-tested techniques heights, diameters and age were determined for forest stand (for all wood types). Natural wood plant revegetation was studied by means of tapes (2-4 tapes 
per a plot) 20 meters in length and the 4 meters in width, set for $2 \times 2 \mathrm{~m}$ platforms. Species composition, projective cover and productivity are defined for a herb and shrub layer. To achieve this purpose, $15-20$ subplots of $1 \times 1 \mathrm{~m}$ were mapped.

\section{Results and Discussion}

Continuing the research on diversity and dynamics of the Ural mountain forest initiated by E.M. Filroze $(1968 ; 1978)$ and B.P. Kolesnikov et al. (1973), we studies old-growth forests the structure of which is similar to climax communities. These include 120-300-year-old forest plots which were not exposed to continuous cuttings, crowning fires and large-scale wind throws over this period of time. Such forests remained on incredibly small areas and are of exclusive interest as a population, and forest typological research object. The research was being conducted from 1991 to 2017.

We studied 2 generalized topographic and ecological profiles: consisting of 9 most widespread forest types in the Southern Urals (Ivanova, 2000, 2007, 2012) and of 12 forest types in the Middle Urals (Ivanova, Zolotova, 2011, 2013, 2015). The main forest forming species of the western Southern Ural low-hill terrains are Siberian spruce (Picea obovata Ledeb.) and Siberian fir (Abies sibirica Ledeb.). Tilia cordata Mill is common everywhere in the forest second layer and undergrowth. However, the tree layer in the top altitudinal belt is formed by Picea obovata only. Contrast temperature conditions confine Abies sibirica Ledeb. and Tilia cordata Mill vegetative propagation. White birch (Betula pubescens Ehrh.) is also a usual forest ecosystem element in the Southern Ural Mountains but it forms native forest stands only in steadily water-logged habitats. There are wood types of broad-leaved forests in the undergrowth of dark-coniferous forests at the middle warmest parts of slopes: Acer platanoides L., Ulmus glabra Huds., Quercus robur L.
Scotch pine (Pinus sylvestris L.) is the main forest-forming species in the Zauralsky hilly piedmont province of the Middle Urals. At tops and upper parts of slopes, it forms pure forest stands mixed with some birch (Betula pubescens Ehrh., B. pendula Roth) and larch (Larix sibirica Ledeb.). In the middle parts of slopes, pine second layer is formed by Tilia cordata Mill. High-productive fir forests grow in the lower parts of slopes in deep clay-loam soils.

Our advanced research is devoted to studying subordinated layers of forest community. The research has complemented data on forest types which are available in literature with information on productivity and species saturation for a herb and shrub layer of nominally primary forests. The obtained data characterize a natural biodiversity level required to preserve natural ecosystem stability (Zolotova, 2013, Ivanova, Zolotova, 2011, 2013, 2015). The results of this part of the research are given in Table 1 and 2 . It is revealed that old-growth coniferous forests of the Southern and the Middle Urals are characterized by similar specific vegetation diversity. This peculiarity is clearly distinct despite the fact that differences in the amount of precipitation in two studied areas lead to change of the prevailing tree species: dark-coniferous forests in the western slope of the Ural Mountains are changed by light-coniferous forests in the eastern macroslope. Preservation of a stable floristic diversity level is achieved by means of species composition change and represents an adaptive ecosystem strategy allowing sustainable functioning even at a significant change in water and temperature conditions. However, there are differences revealed between the studied areas in species saturation, projective cover and herb and shrub layer bioomass. For the Zauralsky hilly piedmont province, these indicators have higher values. This feature can be explained with a strong edificator influence (Siberian spruce) on subordinate vegetation composition.

\begin{tabular}{|c|c|c|c|c|c|c|c|c|}
\hline \multicolumn{3}{|c|}{ Projective cover, $\%$} & \multicolumn{3}{|c|}{ Oven-dry mass, $\mathrm{g} \mathrm{m}^{-2}$} & \multicolumn{3}{|c|}{ Number of species per $1 \mathrm{~m}^{2}$} \\
\hline Average & Maximum & $\mathrm{Cv}$ & Average & Maximum & $\mathrm{Cv}$ & Average & Maximum & $\mathrm{Cv}$ \\
\hline $\begin{array}{l}\text { Upper alt } \\
\text { Unstable } \\
\text { Spruce W }\end{array}$ & $\begin{array}{l}\text { nal belt (700 } \\
\text { noistening c } \\
\text { olygonum a }\end{array}$ & $\begin{array}{l}0 \text { mete } \\
\text { litions } \\
\text { um }\end{array}$ & above sea & vel). Steep sl & & & & \\
\hline 33,9 & 70,2 & 60,8 & 28,0 & 55,7 & 70,5 & 5 & 10 & 30,0 \\
\hline $\begin{array}{l}\text { Middle al } \\
\text { Stable soi } \\
\text { Nemoros }\end{array}$ & $\begin{array}{l}\text { inal belt ( } 50 \\
\text { istening con } \\
\text { uce forest }\end{array}$ & $\begin{array}{l}00 \text { met } \\
\text { ons }\end{array}$ & above sea & vel). Smootl & lopes & & & \\
\hline 77,6 & 97,0 & 12,2 & 73,7 & 127,0 & 68 & 8 & 11 & 18,0 \\
\hline $\begin{array}{l}\text { Lower alt } \\
\text { Stable soi } \\
\text { Moss spr }\end{array}$ & $\begin{array}{l}\text { nal belt ( } 400 \\
\text { istening con } \\
\text { orest }\end{array}$ & $\begin{array}{l}0 \text { mete } \\
\text { ons. }\end{array}$ & above sea & el). Smooth & ppes & & & \\
\hline 30,6 & 83,7 & 23,2 & 32,6 & 77,9 & 79,1 & 10 & 15 & 21,0 \\
\hline
\end{tabular}

Cv: Coefficient of variation, $\%$ 
Table 2: Herb and shrub layer of the studied coniferous old-growth forests of the Middle Urals

\begin{tabular}{|c|c|c|c|c|c|c|c|c|}
\hline \multicolumn{3}{|c|}{ Projective cover, $\%$} & \multicolumn{3}{|c|}{ Oven-dry mass, $\mathrm{g} \mathrm{m}^{-2}$} & \multicolumn{3}{|c|}{ No. of species per $1 \mathrm{~m}^{2}$} \\
\hline Average & Maximum & $\mathrm{Cv}$ & Average & Maximum & $\mathrm{Cv}$ & Average & Maximum & Cv \\
\hline \multicolumn{9}{|c|}{$\begin{array}{l}\text { Drainage habit areas } \\
\text { Steep slopes. Unstable soil moistening conditions. } \\
\text { Cowberry pine forest (Pine forest with Vaccinium vitis-idaea) }\end{array}$} \\
\hline 29,9 & 67 & 67,8 & 78,0 & 195 & 77,5 & 8 & 14 & 37,7 \\
\hline \multicolumn{9}{|c|}{$\begin{array}{l}\text { Middle parts of rolling and smooth slopes. } \\
\text { Stable soil moistening conditions. } \\
\text { Berry pine forest (Pine forest with Vaccinium myrtillus, Rubus saxatilis, Fragaria vesca and undergrowth of Pinus sylvestris) }\end{array}$} \\
\hline 51,4 & 94,5 & 41,9 & 116,4 & 243,6 & 52,6 & 8 & 11 & 18,0 \\
\hline
\end{tabular}

Berry and lime pine forest (Pine forest with a second layer of linden (Tilia cordata) and rare undergrowth of coniferous plants)
57,6
78,0
22,2
69,7
81,6
78
17
2120,0

Moss and berry pine-spruce forest (Pine forest with spruce and moss cover)
29, 7
89,6
91,3
41, 9
112,3
93,6
11
21
66,9

Bracken pine forest (Pine forest with Pteridium aquilinum and rare undergrowth of coniferous plants)

\begin{tabular}{llllllll}
\hline 83,7 & 100 & 17,3 & 123,2 & 184,1 & 21,9 & 15 & 18
\end{tabular}

Herb and lime pine forest (Pine forest with spruce, second layer of linden, spruce and fir and multispecies herbaceous layer)

$\begin{array}{llllllll}39,2 & 100 & 77,4 & 59,3 & 91,1 & 38,8 & 14 & 21\end{array}$

Lower parts of rolling slopes.

Stable, intermittently excessive soil moistening conditions

Multi-herb pine forest (Pine forest with well developed multispecies herbaceous layer)

\begin{tabular}{llllllll}
\hline 86,3 & 100 & 19,5 & 89,8 & 113,1 & 12,6 & 28 & 91
\end{tabular}

Mossy and myrtillus pine forest with a dark-coniferous layer (Pine forest with well developed second spruce layer and moss cover)

$\begin{array}{lllllllll}68,3 & 76 & 7,6 & 143,7 & 165,1 & 11,9 & 11 & 12 & 12,3\end{array}$

Herb and moss spruce forest (Spruce forest with Oxalis acetosella)

\begin{tabular}{llllllll}
\hline 82,6 & 100 & 21,8 & 21,7 & 29,9 & 30,4 & 10 & 15
\end{tabular}

Slightly drained and water-logged habitats

Periodic excessive soil moistening

Multi-herb and tallgrass pine-spruce forest (Pine-spruce forest with well developed herbaceous layer and undergrowth of Picea obovata and Abies sibirica)

\begin{tabular}{lllllllll}
\hline 63,2 & 70,3 & 13,2 & 51,4 & 69,6 & 22,1 & 18 & 23 & 14,8
\end{tabular}

Equisetic and mossy spruce-Siberian cedar forest (Dark-coniferous forest with Siberian pine and continuous cover of mosses)

\begin{tabular}{lllllllll}
\hline 73,4 & 100 & 24,1 & 54,8 & 67,2 & 17,9 & 12 & 15,3
\end{tabular}

Stable excessive soil moistening

Sphagnous and equisetic pine forest (Pine forest with sphagnum mosses)

\begin{tabular}{lllllllll}
\hline 42,9 & 48,8 & 11,8 & 54,0 & 72,1 & 24,4 & 14 & 20 & 27,8 \\
\hline
\end{tabular}

Cv: coefficient of variation

The derived conclusion is also confirmed by comparison of subordinated forest layer productivity (dark-coniferous and light-coniferous forests) within one forest vegetation province (the Zauralsky hilly piedmont province). Comparative analysis has shown that lower layers have the minimum productivity under a shelterwood of the dark-coniferous forest.
Species saturation of the subordinated layers relates to the relief. This indicator takes the minimum values at steep slopes and at the upper mountain parts, both in the Southern Urals, and in the Middle Urals. Minimum values are identified at steep and rolling slopes for Spruce with Polygonum alpinum in the Southern Urals and for Cowberry pine forests in the 
Middle Urals. The largest species saturation is revealed in the lower parts of smooth slopes for moss spruce forests of the Southern Urals and for Multi-herb pine forest of the Middle Urals (Table 2).

A floristic diversity analysis revealed that the pronounced ecotone effect is of great importance for forest species composition formation. The Eastern European lime-oak and lime forests on the one hand and the Southern Taiga darkconiferous forests and broad-leaved and dark-coniferous subtaiga forests on the other hand have an impact on forest type formation at the western low-hill terrains of the Southern Urals. Forest types in the Zauralsky hilly piedmont province are formed on the joint of two subzone vegetation groups: light-coniferous and dark-coniferous taiga-like boreal forests and hemiboreal light-coniferous green forests. Under the conditions of excessive moistening, intrazonal non-forest vegetation types have an impact on a species composition in both regions: swamps and water meadows, which even more severely complicates regularities of species composition formation.

\section{Conclusion}

As a result of the research, we obtained data which characterize a natural biodiversity level required to preserve ecosystem sustainability. The carried-out analysis has shown the advantages for joint use of forest typology, landscape ecology and floristic analysis methods through the obtained measurable parameters of type productivity for forest vegetation research. The conducted work forms a scientific basis for biodiversity preservation of the Ural mountain forests, research of their regional and landscape dynamics, justified forecast of the forest resource condition.

\section{Acknowledgement}

The paper is written under the State order of the Botanical garden of the Ural Department of the Russian Academy of Sciences.

\section{Reference}

Alisov, B.P., 1956. Climate of the USSR. MSU publishing house, Moscow, 128.

Anuchin, N.P., 1982. Forest estimation: the textbook for Higher Education Institutions. Forest industry publishing house, Moscow, 552.

Braun-Blanquet, J., 1964. Pflanzensociologie. Grundzuge der Vegetationskunde. 3 Aufl. Wien-New York: SpringerVerlag, 865.

Chen, I.C., Hill, J.K., Ohlemüller, R., Roy, D.B., Thomas, C.D., 2011. Rapid range shifts of species associated with high levels of climate warming. Science 333(6045), 1024-1026

Filroze, E.M., 1968. Natural characteristics and a mountain forest system of the Southern Urals. The Ural forests and their economy 2, 43-47.

Filroze, E.M., 1978. Anthropogenic dynamics of forest resources of Chelyabinsk region. In: Protection and efficient use of biological resources of the Urals. Sverdlovsk, 63-64.

Global Biodiversity Outlook 2. 2006. Montreal: Secretariat of the Convention on Biological Diversity. Available from: https://www.cbd.int/doc/gbo/gbo2/cbd-gbo2-en.pdf

Ivanova, N., 2017. Research Methods of Timber-Yielding Plants (in the Example of Boreal Forests). In: Heya, M.N., Maiti, R., Pournavab, R.F., Carrillo-Parra, A. (Eds.), Biology, Productivity and Bioenergy of Timber-Yielding Plants, Springer, Cham, 121-137.

Ivanova, N.S., Zolotova E.S., 2013. Biodiversity of the natural forests in the Zauralsky hilly piedmont province. Modern problems of education and science 1 . Available from: https://www.science-education.ru/en/article/ view ? id $=8563$

Ivanova, N.S., Zolotova, E.S., 2015. Ecological space of nominally primaryforest types in the Middle Ural Mountains. Modern problems of science and education 3. Available from: https://www.science-education.ru/en/article/ view?id=19372

Ivanova, N.S., 2000. Methods for the classification of mountain forests in the Southern Urals, Russian Journal of Forest Science (Lesovedenie) 4, 16-21.

Ivanova, N.S., 2007. Productivity dynamics of herb and shrub layer in forests of the western low-hill terrains of the Southern Urals. Botanical journal 92 (9), 1427-1442.

Ivanova, N.S., 2012. Forest types of the western low-hill terrain of the Southern Urals. Izvestia of the Samara scientific center RAS 1, 1020-1023.

Ivanova, N.S., Zolotova, E.S., 2011. Factors of a typological and species diversity of the Zauralsky hilly piedmont province forests. Fundamental Research 12 (2), 275-280.

Ivanova, N.S., Zolotova, E.S., 2014. Development of Forest Typology in Russia. International Journal of Bio-resource and Stress Management 5 (2), 298-303.

Kolesnikov, B.P., 1956. Siberian cedar forests of the Far East. USSR Academy of Sciences publishing house, Moscow, 264.

Kolesnikov, B.P., Zubareva, R.S., Smolonogov, E.P., 1973. Forest vegetation conditions and forest types of Sverdlovsk oblast. Field guidance. Sverdlovsk: Scientific Training Center. the USSR Academy of Sciences, 176.

Kuvshinova, K.V., 1968. Climate. In: Gerasimov, I.P. (Eds.), Urals and Cisural region, Nauka, Moscow, 82-117.

Lankin, Y.P., Ivanova, N.S., 2011. A comprehensive approach to modeling ecosystem diversity of the biosphere on the basis of fundamental natural system properties. Modern problems of science and education 6. Available from: https://www.science-education.ru/en/article/ view ? id $=4883$

Maiti, R., Rodriguez, H.G., Ivanova, N.S., 2016. Autoecology 
and Ecophysiology of Woody Shrubs and Trees: Concepts and Applications. John Wiley \& Sons, 352.

Martynenko, V.B., Mirkin, B.M., Zhigunov, O.Y., 2007. Value of a Braun-Blanquet method in plant biological diversity research. The Siberian Ecological Journal 1, 111-118.

Martynenko, V.B., Solomeshch, A.I., Zhirnova, T.V., 2003. The Bashkiriya Nature Reserve forests: syntaxonimy and nature protection importance. Ufa: Gilem, 203.

Mirkin, B.P., Martynenko, V.B., Wide, P.S., Naumova, L.G., 2010. The analysis of factors which define species wealth of forest communities of the Southern Ural. General Biology Journal 71(2), 131-143.

Murray, D.L., Peers, M.J.L., Majchrzak, Y.N., Wehtje, M., Ferreira, C., Pickles, R.S.A., et al., 2017. Continental divide: Predicting climate-mediated fragmentation and biodiversity loss in the boreal forest. PLoS ONE 12 (5). https://doi.org/10.1371/journal.pone.0176706

Schaphoff, S., Christopher, P.O., Reyer, Schepaschenko, D., Gerten, D, Shvidenko, A., 2016. Tamm Review: Observed and projected climate change impacts on Russia's forests and its carbon balance. Forest Ecology and Management 361, 432-444.

Westgate, M.J., Likens, G.E., Lindenmayer, D.B., 2013. Adaptive management of biological systems: a review. Biological Conservation 158, 128-139. https://doi. org/10.1016/j.biocon.2012.08.016

Yarmishko, V.T., Lyanguzova, I.V., 2002. Methods of forest community study / under the editorship of V.T., Yarmishko, I.V., Lyanguzova. SPb.: Research Institute of Chemistry of St.Petersburg State University, 240.

Zobel, M., 2016. The species pool concept as a framework for studying patterns of plant diversity. Journal of Vegetation Science 27 (1), 8-18.

Zolotova, E.S., 2013. Forest and typological peculiarities of vegetation and soils in the Zauralsky hilly piedmont province: Ph.D, Biology thesis. Yekaterinburg, 208. 